\title{
Economics of Western Juniper Control in Central Oregon
}

\author{
Gwendolyn A. Aldrich, ${ }^{1}$ John A. Tanaka, ${ }^{2}$ \\ Richard M. Adams, ${ }^{3}$ and John C. Buckhouse ${ }^{4}$ \\ Authors are ${ }^{1} \mathrm{PhD}$ Candidate, Department of Economics, University of New Mexico, \\ Albuquerque, NM 87131; ${ }^{2}$ Associate Professor and ${ }^{3}$ Professor, Agricultural and Resource Economics Department, \\ Oregon State University, Corvallis, OR 97331; and ${ }^{4}$ Professor, Department of Rangeland Resources, \\ Oregon State University, Corvallis, OR 97331.
}

\begin{abstract}
The economic and ecological benefits and control costs of western juniper (Juniperus occidentalis Hook) management on rangelands are evaluated using a discrete-time, dynamic economic model developed to depict 4 representative ranches in the John Day region of north-central Oregon. The model's optimization criterion is to maximize the net present value of profits through decisions regarding herd size and composition, cattle sales, and the manipulation of forage production through juniper management practices. Projections are made regarding the impacts of economically optimal juniper management on wildlife populations, stream flows, and erosion levels. Results consistently showed that juniper management options resulted in larger equilibrium herd sizes and greater economic returns. Erosion levels were substantially lower in scenarios that contained juniper management options. Economically optimal juniper management decisions led to increased quail and elk populations, but generally resulted in decreased deer populations. The results indicate there are both economic and ecological benefits from controlling western juniper on Oregon rangelands.
\end{abstract}

\section{Resumen}

Los beneficios económicos y ecológicos del manejo del "Western juniper" (Juniperus occidentalis Hook) sobre los pastizales son evaluados usando un modelo discreto-tiempo y económico dinámico, desarrollado para describir 4 ranchos representativos de la región John Day del norte-centro de Oregon. El criterio de optimización del modelo es maximizar el valor neto presente de las ganancias a través de decisiones respecto al tamaño y composición del hato, venta de ganado y la manipulación de la producción de forraje mediante practicas de manejo del "Juniper". Las proyecciones son hechas en relación a los impactos del manejo económicamente optimo del "Juniper" sobre las poblaciones de fauna silvestre, corrientes de agua y niveles de erosión. Los resultados mostraron consistentemente que las opciones de manejo del "Juniper" resultaron en tamaños de hato de mayor equilibrio y mayores retornos económicos. Los niveles de erosión fueron substancialmente menores en escenarios que contenían opciones de manejo del "juniper". Las decisiones del manejo económicamente optimo del "Juniper" condujeron a mayores poblaciones de codornices y alces, pero generalmente resultaron en una disminución de las poblaciones de venado. Los resultados indican que al controlar el "Western juniper" en los pastizales de Oregon se obtienen tanto beneficios económicos como ecológicos.

Key Words: Juniperus occidentalis, rangeland economics, modeling, wildlife, erosion

\section{INTRODUCTION}

Historically, western juniper (Juniperus occidentalis Hook) grew only on rocky mesa tops and plateaus, although a variety of natural and anthropogenic changes have led to significant expansion of its range during the last 150 years. Although substantial research has been conducted to quantify relationships between juniper and numerous environmental attributes, including erosion and sediment yield, stream flow, vegetation production, and wildlife populations (e.g., Aro 1971; Clary 1974; Short and Boeker 1977; Buckhouse and Mattison 1980;

At the time of the research, the senior author was a master's student, Agricultural and Resource Economics Department, Oregon State University.

Correspondence: John Tanaka, Eastern Oregon Agricultural Research Center-Union Station, P0 Box E, Union, OR 97883. Email: John.Tanaka@oregonstate.edu

Manuscript received 22 April 2004; manuscript accepted 18 June 2005.
Buckhouse and Gaither 1982; Baker 1984; Vaitkus and Eddleman 1987), little research has attempted to integrate the ecological and economic aspects of juniper encroachment and juniper control.

Ogden (1987) provided a simulation model for evaluating consequences of pinyon-juniper management on steer operations. The model was limited in that it considered only benefits to the steer operation. Juniper control costs, environmental externalities, and other potential revenue sources were not considered. A benefit-cost analysis presented by Clary et al. (1974) compared costs of juniper treatment with benefits derived from increased grazing capacities and water yields. Other potential benefits were mentioned but not valued.

Evans and Workman (1994) used linear programming to assess the optimal combination of revegetation, burning, and chemical brush control for use in addressing spring forage bottlenecks on upland loam and upland shallow loam range sites in Utah. Although their approach accounted for treatment 
Table 1. Area and age of juniper encroached riparian areas and uplands in rangeland pastures in the Small cow/calf operation in the High precipitation zone.

\begin{tabular}{|c|c|c|c|c|}
\hline \multirow[b]{2}{*}{$\begin{array}{l}\text { Juniper stand } \\
\text { age (years) }\end{array}$} & \multicolumn{2}{|c|}{ Riparian area (ha) } & \multicolumn{2}{|c|}{ Upland area (ha) } \\
\hline & $\begin{array}{l}\text { North } \\
\text { slope }\end{array}$ & $\begin{array}{l}\text { South } \\
\text { slope }\end{array}$ & $\begin{array}{l}\text { North } \\
\text { slope }\end{array}$ & $\begin{array}{l}\text { South } \\
\text { slope }\end{array}$ \\
\hline 5 & 0.28 & 0.2 & 13.72 & 9.8 \\
\hline 15 & 0.28 & 0.2 & 13.72 & 9.8 \\
\hline 25 & 0.28 & 0.2 & 13.72 & 9.8 \\
\hline 35 & 0.28 & 0.2 & 13.72 & 9.8 \\
\hline 45 & 0.28 & 0.2 & 13.72 & 9.8 \\
\hline 55 & 1.12 & 0.8 & 54.88 & 39.2 \\
\hline 65 & 1.12 & 0.8 & 54.88 & 39.2 \\
\hline 75 & 1.12 & 0.8 & 54.88 & 39.2 \\
\hline 85 & 0.28 & 0.2 & 13.72 & 9.8 \\
\hline 95 & 0.28 & 0.2 & 13.72 & 9.8 \\
\hline 105 & 0.28 & 0.2 & 13.72 & 9.8 \\
\hline Total & 5.60 & 4.0 & 274.40 & 196.0 \\
\hline
\end{tabular}

costs and the effects of treatment on the ranch operation, it did not consider the decline in the effectiveness of treatment that occurs with the passage of time, nor potential effects on water quality, stream flows, erosion, and wildlife.

Johnson et al. (1999) considered the economics of juniper control in the Texas rolling plains, with chaining used for initial treatments, and burning used for subsequent maintenance treatments. In contrast to Evans and Workman (1994), Johnson et al. did consider the inverse relationship between juniper canopy cover and forage production. Johnson et al. determined the optimum maintenance treatment cycle given different assumptions regarding the values of a variety of economic and biological variables. When burning occurred, the authors accounted for the decline in forage available to meet the herd's forage requirements, but assumed the difference came from leased pastures without accounting for the potential limited access and increasing cost of leased pastures. As in other previous studies, no accounting was made for other potential benefits (e.g., water, erosion, wildlife) or costs.

Specific objectives of the research presented here are to: 1) develop a quantitative framework for evaluating optimal management practices for a ranch on which western juniper has encroached, and 2) apply the framework to a set of representative ranches located in the John Day Ecological Province of north-central Oregon, the area of the greatest distribution and concentration of western juniper within Oregon.

\section{MATERIALS AND METHODS}

\section{Empirical Model}

The intent of this research is to assess the profitability of western juniper control on ranches in north-central Oregon. From the perspective of the ranch operation, the empirical question may be viewed as a dynamic constrained maximization problem. Specifically, the objective of the operator is assumed to be the selection of a mix of range management practices that maximize the net present value of profits derived from the production of a mix of products, subject to various resource constraints. The constrained maximization problem is solved for 2 representative ranch sizes located in 2 of Oregon's climatic zones, resulting in 4 distinct representative ranches.

Although all 4 representative ranches are analyzed under varying assumptions regarding the level of available management options, this discussion of the model's construction focuses on the $350 \mathrm{cow} / \mathrm{calf}$ operation (Small) found in the 305-406 $\mathrm{mm}$ precipitation zone (High). Model solutions are also derived for a $1000 \mathrm{cow} /$ calf operation (Large) in the High precipitation zone and both a Small cow/calf operation and a Large cow/calf operation in the $229-305 \mathrm{~mm}$ precipitation zone (Low). The model is quantified by the General Algebraic Modeling System (GAMS) using the MINOS solver (Brooke et al. 1992). GAMS code may be obtained from the authors; see Aldrich (2002) for more detailed information pertaining to this research. (The appendix contains a list of equations and variables used in the model. Equations are referenced by means of equation numbers given within square brackets.)

Objective Function. The ranch operator is assumed to maximize the net present value of total revenues minus variable costs (which we term "profits"), where net present values are calculated using a discount rate of $7 \%$. To reflect the duration of time in which a ranch would likely be managed by a particular individual or entity, the model spans 60 years. A terminal value (calculated in Year 60) is included to account for an infinite stream of profits extending beyond the model's planning horizon [1]. Revenues result from sales of calves, yearlings, and cows [2]. Variable costs include the costs of operating the cattle ranch [3] and the costs of juniper management activities [4]. The model assumes future cattle prices are known with certainty. Monthly average livestock prices were used for the period 1 January 1980 to 24 August 2000 (unpublished data supplied by David Weaber, Cattle-Fax, Inc, Centennial, Colorado, 8 September 2000).

Initial Conditions. Initial conditions establish the stock of resources available at time $t=0$. Enterprise budgets (Kerns et al. 1997; Aldrich et al. unpublished enterprise budget) were used to establish initial conditions for cows, first calf heifers, and replacement heifers [5]. Using information obtained from the Crook County Extension Office, initial conditions were also established to define the extent and location of juniper encroachment, and the number of years since last treatment. Specifically, initial conditions established for juniper encroachment describe the extent of current juniper encroachment in riparian and upland areas as well as productivity zones, which are characterized by north and south slopes and by Low and High precipitation zones. Table 1 provides the assumed inventory and status of juniper encroachment for rangeland pastures on the Small cow/calf operation in the High precipitation zone. Similar assumptions were made for each of the 4 representative ranches, although the extent and initial status of juniper coverage varies by productivity zone (T. Deboodt, Oregon State University Extension Service, Prineville, Oregon, personal communication, 2002). Due to the high expense and limited use of mechanical control of juniper, we assumed that the most recent "treatment" on all juniper-encroached acres was either by naturally occurring fire or a prescribed burn. 
Equations of Motion. Equations of motion are necessary to model specific ranch functions, and reflect how the state of the system changes from one time period to the next. The ranch model includes equations of motion that describe how changes in the herd are dependent on time, the herd variables themselves, and management decisions regarding the herd (reflected in the control variables). Also included are equations of motion that describe how the stock of juniper is dependent on time, the present juniper stock, and decisions regarding juniper management.

Ranch Operation Equations of Motion. Calves are born in the spring and sold the following fall. It is assumed that all steer calves are sold [6], while only a portion of the heifer calves are sold [7]; those not sold become replacement heifers the following spring or are sold as yearlings [7 and 8]. Only high-quality replacement heifers are kept to become first calf heifers; all others are culled from the herd as yearlings. It is assumed that conception rates and the need to maintain a highquality herd requires a replacement heifer cull rate of at least $25 \%$ [9]. Another means of maintaining a high-quality herd is to cull (and replace) a certain percentage of the cows and first calf heifers [10]. Based on Oregon State University enterprise budgets, at least $13 \%$ of mature cows and first calf heifers are culled. Additionally, because calves of young mothers have a lower survival rate than calves of experienced mothers, first calf heifers are restricted to no more than $20 \%$ of the total number of mature cows [11].

Juniper Equations of Motion. Five forage sources are included in the model-rangeland pastures, flood-irrigated pastures, purchased hay, public lease, and private lease. The forage source of primary interest is the ranch's rangeland, because this forage source is affected by the juniper stock. As a result of junipers' effective water mining capabilities (Bedell et al. 1993), juniper-encroached land will have lower forage production and will support fewer cattle. Thus, inclusion of equations of motion to reflect juniper management options and decisions is a key component of the model.

The model allows the use of 2 treatment methods-cutting and burning. Cutting refers to using chainsaws to cut and limb trees. It is assumed that slash is scattered across the site to protect the site from erosion, provide a protective habitat for re-establishment of grasses, offer protection from grazing for establishing grasses, and replenish soil nutrients. An average cost for cutting juniper $\left(\$ 32.17 \cdot \mathrm{ha}^{-1}\right)$ is calculated using information provided by Isley (1984). Information given in Campbell (1999) and Martin (1978) is also used to calculate an average cost for burning juniper $\left(\$ 7.04 \cdot \mathrm{ha}^{-1}\right)$. Through the use of 2 accounting equations, the model allows juniper hectares to be treated once, multiple times, or not at all [12 and 13].

Ranch Operation Boundary Conditions. A restriction is imposed on the model so that the ranch must either produce or purchase enough forage to feed the herd throughout the year [14]. Mature cows are considered equivalent to 1.0 animal unit month (AUM), first calf heifers are equivalent to 0.75 AUM, and yearlings are considered to be 0.6 AUM. Costs per animal unit day associated with flood-irrigated pastures, purchased hay, and public lease $(\$ 0.23, \$ 0.85$, and $\$ 0.25$, respectively) are derived from Kerns et al. (1997) and Aldrich et al. (unpublished Oregon State University Enterprise Budget). Forage from rangeland pastures is assumed to incur no additional cost beyond the variable costs incurred through the general ranch operations. An exponential cost function is used for the private lease option, to reflect the limited supply of comparatively economical nearby private pastures available for lease. Although the forage requirements of the herd must be met, additional restrictions are placed on the demand and supply equations for the various feed sources.

Forage production from rangeland pastures is influenced by precipitation, the juniper stock, and juniper management decisions and, in turn, affects the optimal herd size. The model imposes utilization standards to restrict consumption of riparian and upland vegetation to no more than $35 \%$ and $50 \%$, respectively. Sneva and Hyder (1962) used a linear herbage response relationship $(\hat{Y}=1.11 X-10.6$, where $\hat{Y}=$ yield index and $X=$ precipitation index) to predict herbage yields on sagebrush-bunchgrass sites, and to predict animal days of grazing or forage yields. This linear response equation and the utilization standards are combined to estimate forage production from rangeland pastures [15].

Because the ranch has a limited number of flood-irrigated hectares, the number of AUMs available from flood-irrigated pastures is restricted and assumed constant [16]. To ensure the survival of inexperienced replacement heifers, replacements are grazed on flood-irrigated pastures for 8 months (Kerns et al. 1997). Consequently, the 8 -month feed requirement of the replacements must not exceed that supplied by the ranch floodirrigated pastures [17].

Public lands may be leased and used to graze cows and first calf heifers during the summer months, and thus the model assumes the grazing permit provides at most 4 months of feed for cows and first calf heifers, although less may be used if a lower cost feed source is available [18]. Use of public lands is also set at a level within the permittee's lease limit [19]. The model also includes an option to obtain additional forage through the lease of private lands.

The severity of winter weather in eastern Oregon requires that ranchers feed hay to their cattle during the winter months. The model therefore requires a minimum of a 4-month supply of hay be purchased at market price, although additional hay may be purchased if deemed profitable by the model [20].

Juniper Boundary Conditions. Although cutting by hand and burning are considered to be relatively ecologically benign procedures, boundary conditions are required to ensure the methods are used appropriately. Juniper, although highly susceptible to fire when young, becomes less so with age, and when the juniper canopy cover reaches about $50 \%$ of the maximum canopy cover for a particular site, there will no longer be sufficient fine fuels to use fire as a treatment method (R. Miller, Oregon State University, Eastern Oregon Agricultural Research Center, Burns, Oregon, personal communication, 2002). Prescribed burning is thus restricted to sites with less than $50 \%$ of their maximum canopy cover [21] and, as a result, older stands must be cut rather than burned, despite cutting being more expensive. Stands on which the most recent control was cutting are assumed to reach $50 \%$ of the maximum canopy cover in 63 years; stands that were most recently burned are assumed to reach $50 \%$ of the maximum canopy cover in 73 years. The 10-year difference results from the fact 
Table 2. Potential forage yields in upland and riparian areas on north and south slopes in the Low and High precipitation zones.

\begin{tabular}{|c|c|c|c|c|}
\hline \multirow[b]{3}{*}{ Site location } & \multicolumn{4}{|c|}{ Productivity zone } \\
\hline & \multicolumn{2}{|c|}{ Low precipitation } & \multicolumn{2}{|c|}{ High precipitation } \\
\hline & $\begin{array}{l}\text { North } \\
\text { slope }\end{array}$ & $\begin{array}{l}\text { South } \\
\text { slope }\end{array}$ & $\begin{array}{l}\text { North } \\
\text { slope }\end{array}$ & $\begin{array}{l}\text { South } \\
\text { slope }\end{array}$ \\
\hline \multicolumn{5}{|c|}{$\left(\mathrm{kg} \cdot \mathrm{ha}^{-1}\right)$} \\
\hline Upland & 1140 & 642 & 1389 & 1072 \\
\hline Riparian & 2280 & 2280 & 2280 & 2280 \\
\hline
\end{tabular}

that prescribed burning removes both trees and brush from the site, while cutting removes only juniper, leaving all brush and juniper seedlings in place. This, in combination with the fact that one of the most common establishment sites for juniper is under sagebrush, causes cut sites to reach $50 \%$ of maximum canopy cover faster than burned sites (R. Miller, Oregon State University, Eastern Oregon Agricultural Research Center, Burns, Oregon, personal communication, 2002).

A second restriction on juniper management is included to ensure passage of a minimum of 10 years between the time a stand is cut and the time it is burned [22]. The 10-year interval allows grasses to become fully established (important for regeneration) and provides sufficient time for most juniper seeds to germinate. Burning a site after juniper seeds have germinated, but before the new trees reach sexual maturity, serves to eliminate the juniper seedbed from the site over time (L. E. Eddleman, Department of Rangeland Resources, Oregon State University, Corvallis, Oregon, personal communication, 1995).

Accounting Equations. Accounting equations are required to track herbaceous vegetation production, sedimentation, and wildlife populations. The calculation of herbaceous vegetation production in year $t$ takes into consideration the potential yield of various sites of the ranch, such as riparian or upland areas and north- or south-facing slopes, and that certain portions of the ranch may (not) be ecologically unsuited to support juniper. Potential yield numbers (Table 2) reflect the productivity of sites when not encroached by juniper. Values were calculated using data from Natural Resource Conservation Service Site Descriptions of sites within the John Day Ecological Province, and reflect the annual production (air-dry weight in $\mathrm{kg} \cdot \mathrm{ha}^{-1}$ ) of forage vegetation, given average precipitation levels for each site (USDA 1990).

As junipers encroach, sites become less able to support other vegetation. The degree of decline in forage yields is a function of the most recent method of juniper treatment, aspect of the site (north or south slope), and age of the juniper stand (the older the stand, the greater the suppression of herbaceous species) [23 and 24]. The baseline and treatment scenarios both account for changes in herbaceous vegetation that occur over time due to increases in the juniper canopy-potential yields are assumed to decline linearly as the age of the juniper stand increases. The treatment scenario also accounts for changes in herbaceous vegetation production that occur as a result of juniper treatment activities—cutting and burning both "reset" the age of the juniper stand to 0 . A decline in potential yields begins immediately in areas where juniper are cut, but burning provides 10 years of $100 \%$ potential yields, although grazing is proscribed for the first 2 years after burning. Although both north and south slopes exhibit the same initial decline in forage production as juniper invades a site, production on north slopes typically will not drop below $50 \%$ of the potential yield for that site, while south slopes will continue to degrade until there is essentially nothing but juniper on the site (R. Miller, Oregon State University, Eastern Oregon Agricultural Research Center, Burns, Oregon, personal communication, 2002).

Accounting equations are also used to estimate changes in the levels of soil erosion and wildlife populations that result from the ranch operator's juniper management decisions. Soil loss is estimated using the Modified Soil Loss Equation (MSLE) (Brooks et al. 1997) [25 and 26]. The MSLE provides an estimate of erosion and has been applied to many sites and, although alternative approaches for estimating soil loss have been developed, the MSLE is still the most widely used technique. Due to the inherent limitations in applying the MSLE to nonagricultural areas, the reader is cautioned that emphasis should be placed on relative erosion estimates rather than quantitative erosion estimates.

Hawkins (1987) used the Universal Soil Loss Equation (USLE) - the original form of the MSLE-to calculate erosion on a typical pinyon-juniper site. We apply the same rainfall erosivity factor $(R)$, soil erodibility factor $(K)$, and slope gradient and length factor $(L S)$ values to the representative juniper sites modeled here. We use cover factors $(C)$ provided by Brooks et al. (1997) for pasture, rangeland, and grazed woodland, which requires assumptions regarding the dependence of $C$ on stand age, treatment method, and aspect. We used $C$ values that vary from 0.06 to 0.34 , with the highest values representing freshly burned areas. As burned areas regenerate, $C$ values initially decrease, but ultimately increase as grasses are again displaced by juniper. Using these assumptions, soil erosion and potential stream sedimentation are estimated for each representative ranch.

Wildlife habitats, and therefore wildlife populations, are also influenced by the prevalence of juniper. Production relationships are included to assess the effects of juniper and juniper management on mule deer (Odocoileus hemionus Rafinesque) [27], elk (Cervus elaphus Erxleben) [28], and quail (Callipepla lophortyx Californicus) populations [29 and 30]. Interest in the populations of these particular species stems from the potential for ranchers to lease the rights to engage in high-quality hunting activities on their lands, for which hunters have demonstrated a high level of willingness to pay (Sorg and Nelson 1986; Fried 1993). A lack of detailed information regarding the effect of juniper on wildlife populations necessitates only rough population estimates and an emphasis on relative changes.

Information obtained from the USDA (1979) and D. Bruning (Oregon Department of Fish and Wildlife, John Day, Oregon, personal communication, 2002) was used to estimate potential fall season deer and elk carrying capacities for each ranch, assuming the ranch provided optimal habitat for the particular species. Because deviations from optimal habitat result in population declines, equations are included to calculate deer and elk populations as functions of ranch size, precipitation, and the extent of juniper encroachment. However, research on the effects of juniper encroachment on mule deer and elk is limited, and current information enables only 
Table 3. Effects of ranch size and precipitation on average profits and equilibrium herd size.

\begin{tabular}{|c|c|c|c|c|}
\hline \multirow{2}{*}{$\begin{array}{l}\text { Ranch } \\
\text { size }\end{array}$} & \multirow{2}{*}{$\begin{array}{l}\text { Precipitation } \\
\text { zone }\end{array}$} & \multicolumn{2}{|c|}{$\begin{array}{c}\text { Annualized } \\
\text { profits }\left(\$ \cdot \text { year }^{-1}\right)\end{array}$} & \multirow{2}{*}{$\begin{array}{c}\text { Equilibrium } \\
\text { herd size (head) }\end{array}$} \\
\hline & & Nominal & Real $^{1}$ & \\
\hline \multirow[t]{2}{*}{ Small } & Low & 40824 & 9428 & 379 \\
\hline & High & 44423 & 10376 & 379 \\
\hline \multirow[t]{2}{*}{ Large } & Low & 143355 & 34689 & $974^{2}$ \\
\hline & High & 162863 & 38534 & 1085 \\
\hline
\end{tabular}

${ }^{1} \mathrm{~A} 7 \%$ discount rate it used to convert nominal to real values.

${ }^{2}$ The $1000 \mathrm{cow} /$ calf operation in the Low precipitation zone never reaches an equilibrium herd size. The herd size listed here is an average of the herd size in periods 2 through 44 (all time periods except those in which the herd size is increasing in order to maximize the terminal value).

gross estimates of population changes. The following figures are included in the model to provide rough estimates of changes in deer and elk populations. Deer show preference for areas that provide roughly $60 \%$ forage and $40 \%$ (USDA 1979) cover, with edge areas (e.g., areas along the edge of meadows) typically exhibiting the highest use and concentration of deer. Elk generally prefer areas that provide proportionately more forage $(60 \%-85 \%)$ and less cover (between $40 \%$ and $15 \%$ ) (USDA 1979). A ranch that provides the optimal habitat mix for deer was assumed to have a deer herd of a size equivalent to the fall season deer carrying capacity, while a ranch that provides the optimal habitat mix for elk was assumed to have an elk herd equivalent in size to the fall season carrying capacity for elk. Deviations from the optimal habitat mix result in reduced deer and elk herds, although deer appear to be less sensitive to deviations from optimal habitat conditions than elk. A large $(70 \%$ ) deviation from the optimal $60 \%$ forage, $40 \%$ cover mix is required before deer populations are noticeably affected, whereas elk populations decline as a result of a $1 \%$ deviation from optimal habitat (USDA 1979).

The presence of quail provides another potential revenue source for ranchers. Optimal quail habitat consists of areas of bare ground, herbaceous vegetation, and scattered brush, and supports an average density of roughly 1.25 quail $\mathrm{ha}^{-1}$ (Sullivan 1994). Areas with a significant shrub component can be expected to have quail densities 60\% lower than densities in locales of premium habitat. Abundance (relative to average quail densities in areas of premium habitat) declines sharply with the encroachment of juniper, with a more than $90 \%$ decline in areas exhibiting early and mid stages of juniper encroachment, and a virtual absence of quail from mature juniper stands. These relative abundance estimates are used to calculate a stepped relative abundance function that approximates an exponential decline in quail populations as junipers encroach.

\section{Model Specification}

A baseline scenario (one that does not include juniper management or control) is solved for each combination of ranch size and precipitation level. The solution of the baseline scenario represents management practices for a ranch on which juniper control is not practiced. A second scenario (referred to as the treatment scenario) includes juniper management options, and
Table 4. Effects of ranch size and precipitation zone on the baseline scenario environmental variables over the 60 -year time horizon.

\begin{tabular}{|c|c|c|c|c|c|}
\hline \multirow{2}{*}{$\begin{array}{l}\text { Ranch } \\
\text { size }\end{array}$} & \multirow{2}{*}{$\begin{array}{l}\text { Precipitation } \\
\text { zone }\end{array}$} & \multicolumn{3}{|c|}{$\begin{array}{c}\text { Change in wildlife } \\
\text { populations over time }(\%)^{1}\end{array}$} & \multirow{2}{*}{$\begin{array}{l}\text { Change in } \\
\text { erosion over } \\
\text { time }(\%)^{2}\end{array}$} \\
\hline & & Quail & Deer & Elk & \\
\hline \multirow[t]{2}{*}{ Small } & Low & -26 & 0 & -100 & 10 \\
\hline & High & -32 & 0 & 0 & 12 \\
\hline \multirow[t]{2}{*}{ Large } & Low & -26 & 0 & -100 & 10 \\
\hline & High & -32 & 0 & 0 & 12 \\
\hline
\end{tabular}

${ }^{1}$ Due to limitations in the application of the Modified Soil Loss Equation to nonagricultural areas and to limited knowledge regarding the effect of juniper encroachment on wildlife, only gross estimates of erosion levels and wildlife population numbers are possible. For this reason, we focus on relative changes in erosion levels and wildlife populations.

${ }^{2}$ Percent change is measured from time $=1$ to time $=60$.

is also solved for each of the 4 combinations of ranch size and precipitation level. Analyzing various specifications of the model with respect to precipitation, ranch size, and juniper management allows us to make inferences concerning the effect of resources and juniper management options on profits, herd size, soil erosion, and wildlife populations under a range of ranching conditions. The results of these model simulations are discussed in the next section.

\section{RESULTS}

The solution of each baseline and treatment scenario results in 3 sets of outputs for each state and control variable in the model. The first set is an adjustment period in which resource levels, as defined by the initial conditions, move toward equilibrium levels. The second set represents the steady state or equilibrium, in which variables have the same value during each time period. The final set consists of adjustments made to activity levels to maximize the terminal value. The discussion of results focuses primarily on the first 2 sets of outputs (initial and equilibrium levels), given that these are the values that define behavior under sustained operation of the ranch enterprise.

\section{Baseline Scenario Results}

Table 3 illustrates how ranch size and precipitation affect ranch profits and equilibrium herd size. As expected, the model predicted considerably smaller profits for the Small cow/calf ranches than for the Large cow/calf ranches. Precipitation also has a substantial effect on the model's prediction of the profitability of ranch operations-average profits resulting from the Small cow/calf model in the High precipitation zone are $9 \%$ greater than those of the same sized operation in the Low precipitation zone, and average profits from the Large cow/calf operation in the High precipitation zone are $14 \%$ higher than those of the Large cow/calf operation in the Low precipitation zone.

The model demonstrated that ranch size and precipitation zone not only affect the profitability of ranch operations, but also affect the impact that juniper encroachment has on erosion levels and some wildlife populations (Table 4). Although juniper encroachment causes quail populations to decline in both precipitation zones, deer populations do not appear to be influenced by juniper encroachment in either precipitation 


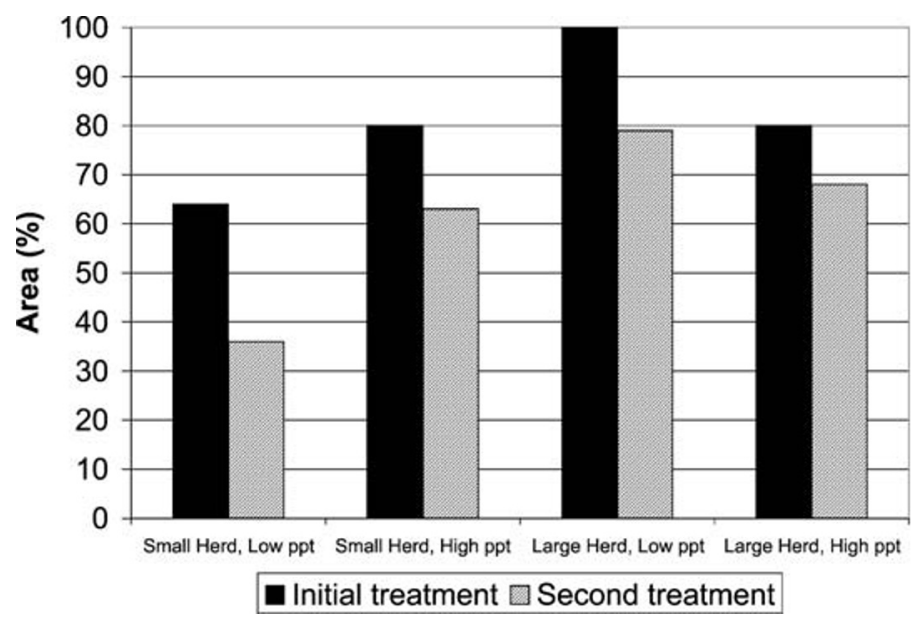

Figure 1. Percent of juniper-encroached area that undergoes initial juniper control treatment and retreatment in later years.

zone. Elk populations, on the other hand, are not significantly affected by juniper encroachment in the Low precipitation zone, but decline as a result of encroachment in the High precipitation zone. The divergence in the change in elk populations between the two precipitation zones results from the fact that juniper-encroached hectares compose a larger portion of ranches in the higher precipitation zone, resulting in a greater loss of forage habitat used by elk.

Results from the baseline scenarios illustrate that erosion and potential stream sedimentation are adversely affected by juniper encroachment (Table 4). Average annual erosion is higher on ranches where more precipitation is received.

\section{Treatment Scenario Results}

Ranch size and precipitation levels affect management decisions regarding the extent of juniper control (Fig. 1). On average, $18 \%$ more of rangeland pastures within the Large cow/calf operations experience an initial juniper treatment than those within the Small cow/calf operations, and $24 \%$ more are retreated. A comparison of different sized operations located in

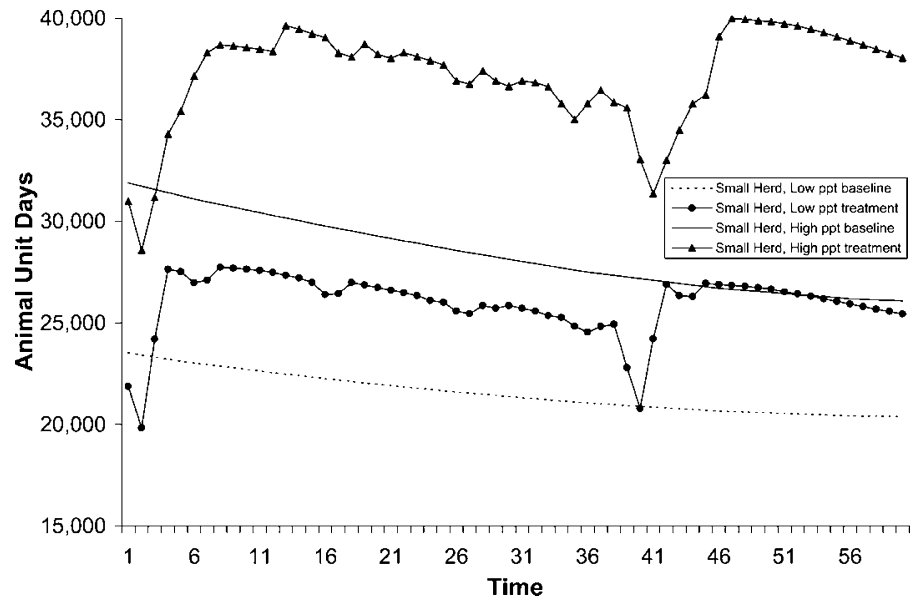

Figure 2. Effects of juniper control treatment on animal unit days of production for Small cow/calf operations in Low and High precipitation zones.

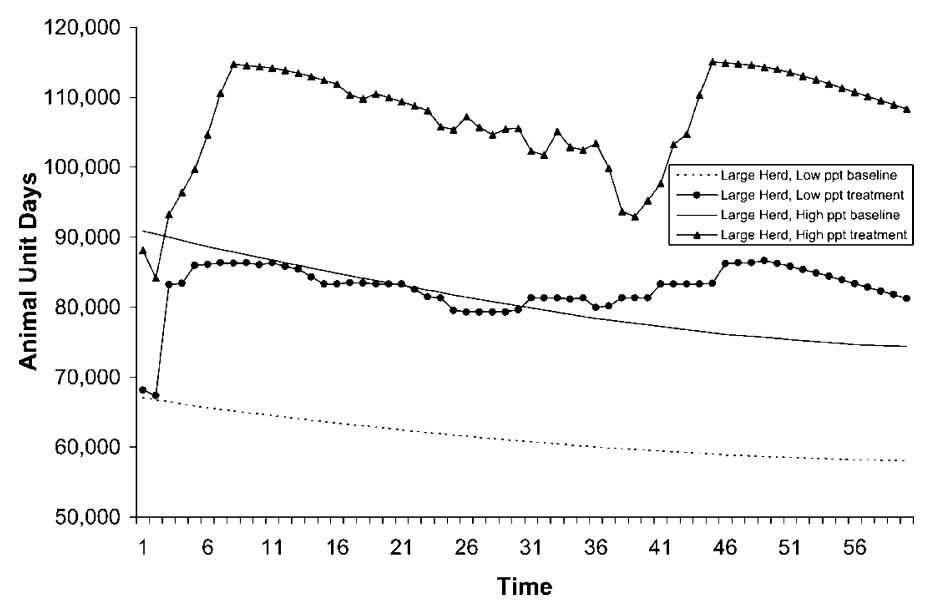

Figure 3. Effects of juniper control treatment on animal unit days of production for Large cow/calf operations in Low and High precipitation zones.

the same precipitation zone illustrates that ranch size does affect the incidence of initial treatment in the Low precipitation zone, but not in the High precipitation zone. The effect of precipitation on management decisions is more ambiguous. Overall, an increase in precipitation is correlated with lower initial juniper treatment but higher secondary treatment (Fig. 1). For the smaller cow/calf operations an increase in precipitation leads to a $16 \%$ increase in initial treatment activity and a $27 \%$ increase in retreatment activity, whereas for the larger cow/calf operations an increase in precipitation leads to a $20 \%$ decrease in initial treatment activity and an $11 \%$ decrease in retreatment activity.

The method used for initial juniper treatments also varies with ranch size and precipitation zone. In the High precipitation zone both the small and large ranches use controlled burns to treat $65 \%$ of the juniper-encroached hectares and manually cut another $15 \%$. In the Low precipitation zone the small and large ranches treat $59 \%$ and $61 \%$, respectively, of juniper-encroached hectares using controlled burns, and manually cut an additional $4 \%$ and $39 \%$, respectively. Retreatment of juniper-encroached areas occurred before juniper stands matured such that they required manual cutting, and thus retreatment always involved the use of the less expensive controlled burn method.

Figures 2 and 3 show changes in the baseline and treatment scenario forage production levels on each ranch over time, and thus illustrate the effect of juniper treatment activities on forage production. Table 5 shows how profits and equilibrium herd size are affected by juniper treatment. As expected, juniper treatment increases the average profits on each ranch, and in all cases except the Small cow/calf operation in the Low precipitation zone, the equilibrium herd size increases. The ranch that profits most from juniper control is the Large cow/calf operation in the Low precipitation zone, for which the average profits increased by $13 \%$ over the baseline scenario. The ranch that profits least from juniper control is the Small cow/calf operation in the Low precipitation zone, where average profits increased by only $5 \%$ from the baseline. That treatment is most common on the Large cow/calf ranch in the Low precipitation zone and least common on the Small cow/calf ranch in the Low precipitation zone (Fig. 1) is consistent with the fact that these 
Table 5. Summary of the baseline and treatment scenario results for average profits and herd sizes for the different ranch sizes and precipitation zones.

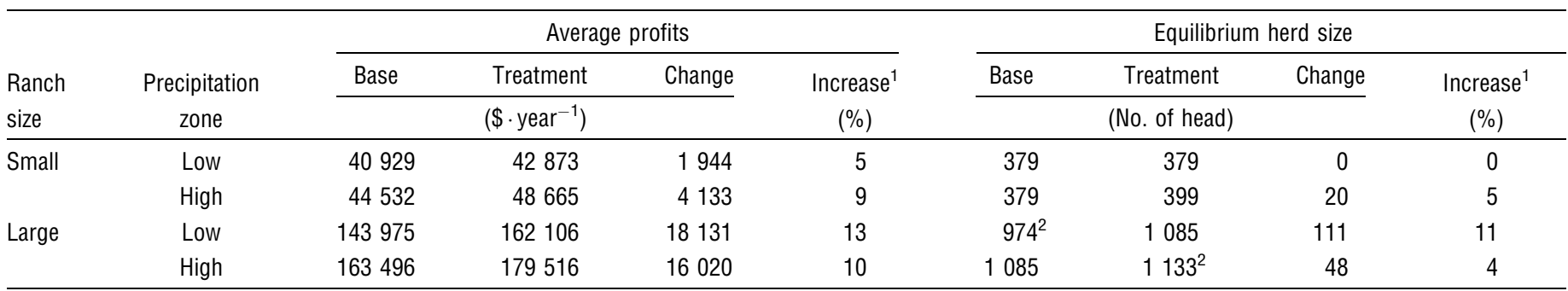

${ }^{1}$ Percent change is measured relative to the baseline scenario.

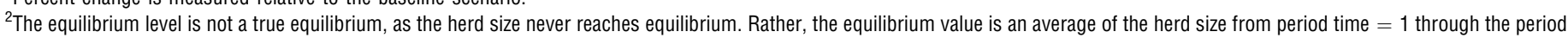
in which the herd size begins to increase in order to maximize the terminal value.

ranches profit the most and the least from the juniper control options, respectively.

As indicated in Table 6, ranch size, precipitation, and juniper management options also affect soil erosion and wildlife population levels. Quail, a ground nesting species, benefit from juniper management activities in all 4 treatment scenarios. The greatest quail densities occur on the Large cow/calf operation in the Low precipitation zone, while the lowest densities occur on the Small cow/calf operation located in the same precipitation zone. A comparison of baseline and treatment quail population densities on the 4 ranches indicates that average densities increased by about $40 \%$ on all ranches except for the Small cow/calf ranch in the Low precipitation zone, where densities increased by $30 \%$.

In most scenarios, deer populations are reduced by juniper treatment. An exception occurs on the Small cow/calf operation in the Low precipitation zone, where deer populations are unaffected by treatment activities. Juniper clearing on this particular ranch is not so extensive to cause cover habitat to decline from the optimal level for deer. In contrast, elk populations generally increase in response to juniper treatment, although on the Large cow/calf ranch in the Low precipitation zone, elk populations decrease because juniper management is most aggressive, and eliminates essentially all cover. The percentage increase in the average elk population relative to the baseline scenarios is greatest for those operations located in the High precipitation zone.

The effect of juniper management on erosion rates depends on the control method used. When junipers are burned, soil is initially left bare and erosion rates rise, but as grasses rejuvenate, erosion rates drop. When junipers are cut, an immediate decline in erosion rates occurs. Overall, juniper management reduces erosion and stream sedimentation, as a protective herbaceous layer is restored following juniper removal. The Large cow/calf ranch in the Low precipitation zone receives the greatest increase in profits from juniper management and is thus the ranch that treats the greatest quantity of juniper $(100 \%)$. As a result, it is also the ranch with the lowest average annual erosion and the greatest percent reduction $(31 \%)$ in average annual erosion. Erosion is reduced the least $(16 \%)$ on the Small cow/calf ranch in the same precipitation zone, where juniper are cleared from less than $70 \%$ of the ranch.

\section{MANAGEMENT IMPLICATIONS}

The results of this research indicate that from both economic and ecological perspectives, ranchers should take a more aggressive approach to juniper clearing than they have in the past. Although control is expensive, especially if stands have matured to the point that they must be manually or mechanically cut, the increases in simulated revenues are greater than the control costs. This raises the question, "Why aren't ranchers clearing juniper more actively?" One explanation may be that knowledge of western juniper is still limited. There are differing viewpoints on the impacts of juniper on herbaceous vegetation production, stream flows, wildlife habitat, and soil erosion. There is also considerable uncertainty regarding the response of ecosystems and herbaceous cover to juniper clearing, and it has been hypothesized that responses are site specific (Belsky 1996).

Table 6. Effect of juniper control treatment on the wildlife numbers and average annual erosion.

\begin{tabular}{|c|c|c|c|c|c|c|c|}
\hline \multirow{3}{*}{$\begin{array}{l}\text { Ranch } \\
\text { size }\end{array}$} & \multirow{3}{*}{$\begin{array}{l}\text { Precipitation } \\
\text { zone }\end{array}$} & \multicolumn{3}{|c|}{ Wildlife species $^{1}$} & \multicolumn{3}{|c|}{ Average annual erosion } \\
\hline & & Quail & Deer & Elk & Base & Treatment & Decrease \\
\hline & & \multicolumn{3}{|c|}{ Baseline/treatment/\% change ${ }^{2}$} & \multicolumn{2}{|c|}{$\left(\mathrm{kg} \cdot \mathrm{ha}^{-1}\right)$} & $\overline{(\% \text { change })^{2}}$ \\
\hline \multirow[t]{2}{*}{ Small } & Low & $514 / 744 / 45$ & $53 / 53 / 0$ & $3 / 40 / 1233$ & 6332 & 5330 & 16 \\
\hline & High & $475 / 796 / 68$ & $53 / 51 /-4$ & $0 / 37 /$ inf $^{3}$ & 6416 & 4809 & 25 \\
\hline \multirow[t]{2}{*}{ Large } & Low & $1464 / 2597 / 77$ & $150 / 121 /-19$ & $8 / 0 /-100$ & 6332 & 4360 & 31 \\
\hline & High & $1353 / 2$ 299/70 & $150 / 139 /-7$ & 0/30/inf ${ }^{3}$ & 6416 & 4743 & 26 \\
\hline
\end{tabular}

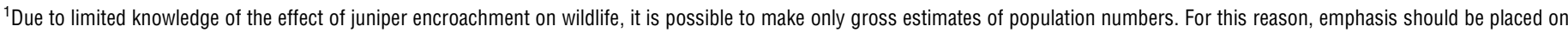
relative changes in erosion levels and wildlife populations.

${ }^{2}$ Percent change measured relative to baseline scenario.

3"inf" denotes an infinite change. 
Additional uncertainty exists concerning the specific responses of both desirable and undesirable vegetative species to juniper treatment. Although a land manager might also be interested in juniper management for the purposes of increased stream flows, this too is a source of uncertainty, as much of the evidence concerning increased stream flows has been anecdotal. Previous case studies regarding juniper control and water yields have had mixed results. In some instances, clearing has resulted in significant increases in stream flows (Bedell 1987; Eddleman and Miller 1992), while in other cases clearing has had negligible results (Williams et al. 1972; Clary 1974).

Another possible explanation for the minimal level of juniper control is the significant amount of risk involved. One source of risk is associated with the uncertainty regarding vegetative responses to treatment, specifically the potential for the proliferation of undesirable species. The potential for a controlled burn to develop into a wildfire is a considerable source of risk, even though it is less than one-fourth the cost of cutting by hand. Minimal juniper control may also be due to cash flow or debt limitations, as juniper treatment is expensive and costs may be prohibitive. In addition, benefits are uncertain and derived over time. This presents an opportunity for government incentive programs to help reduce the financial strain of the costs of juniper control. Ranches provide many ecosystem services and public goods, including wildlife habitat and erosion control (and thus reduced stream sedimentation and longer reservoir life). Subsidies could be paid to ranch operators as payment for the provision of such public goods, and to help pay for the expenses of caring for, managing, and maintaining these public goods.

There are a number of limitations to the model developed and used here. An important modification to the model would be the addition of stochastic prices and stochastic precipitation data to evaluate price and production risks. Consideration of cash flow limitations or the ability to incur debt to treat juniper areas could also provide important constraints. The inclusion of alternative revenue sources is another improvement that could be made to the model. As an example, ranchers in many regions of Oregon lease the trespass or hunting rights on their land. If there is a resident herd of deer or elk that includes trophy bucks or bulls, the trespass right to access trophy animals could potentially provide additional revenues. Other sources of revenue from wildlife may also exist, in which case they should be included in the model. Wildlife and erosion might also be included as decision variables if there was good information pertaining to the values of such benefits at the specific location of the study.

Although the model generally predicts a decline in deer populations as a result of juniper control, this should not be interpreted as evidence that juniper clearing will destroy wildlife habitat and is thus to be avoided. Similarly, the benefits derived from juniper control should not be interpreted as evidence that juniper should be completely eradicated. Most circumstances call for a balanced approach to juniper control, with thoughtful consideration of the ecosystem's complexity and history, as well as the current demands placed on the particular ecosystem.

In conclusion, there appears to be potential for increased ranch profits as a result of reducing the extent of western juniper on rangeland pastures. However, there also are significant financial constraints and sources of risk and uncertainty that appear to deter ranchers from practicing juniper management. The gap between optimal practices and actual current practices illustrates the need for additional research, modeling, educational activities, and possibly, the establishment of government incentive programs. The latter would recognize that some of the benefits of juniper control, such as reduced erosion and hence improved water quality, accrue to society and not just to ranchers.

\section{LITERATURE CITED}

ALDRICH, G. A. 2002. The economics of western juniper management on ranches located in the John Day Ecological Province of North-Central Oregon [thesis]. Corvallis, OR: Oregon State University. $168 \mathrm{p}$.

ARo, R. S. 1971. Evaluation of pinyon-juniper conversion to grassland. Journal of Range Management 24:188-197.

BAKeR, M. B., JR. 1984. Changes in streamflow in an herbicide-treated pinyonjuniper watershed in Arizona. Water Resources Research 20:1639-1642.

BEDELL, T. E. 1987. Rehabilitation of western juniper rangeland; a case history. In: R. L. Everett (CoMP.), Proceedings of the Pinyon-Juniper Conference; 13-16 January 1986; Reno, NV. General Technical Report GTR-INT-215. Ogden, UT: US Department of Agriculture, Forest Service, Intermountain Research Station. p 313-315.

Bedell, T. E., L. E. Eddleman, T. Deboodt, and C. Jacks. 1993. Western juniper-Its impact and management in Oregon rangelands. Extension Circular 1417. Corvallis, OR: Oregon State University Extension Service. $15 \mathrm{p}$.

BeLSKY, A. J. 1996. Viewpoint: western juniper expansion: is it a threat to arid northwest ecosystems? Journal of Range Management 49:53-59.

Brooke, A., D. Kendrick, and A. Meeraus. 1992. GAMS: A user's guide, release 2.25. Danvers, MA: Boyd and Fraser Publishing Company. 289 p.

Brooks, K. N., P. F. Ffolloott, H. M. Gregersen, and L. F. DeBano. 1997. Hydrology and the management of watersheds, 2nd ed. Ames, IA: Iowa State University Press. $502 \mathrm{p}$.

Buckhouse, J. C. AND R. E. Gaither. 1982. Potential sediment production within vegetative communities in Oregon's Blue Mountains. Journal of Soil and Water Conservation 37:120-122.

Buckhouse, J. C., AND J. L. Mattison. 1980. Potential soil erosion of selected habitat types in the High Desert Region of Central Oregon. Journal of Range Management 33:282-285.

CampbelL, R. B., JR. 1999. Ecology and management of pinyon-juniper communities within the Interior West: overview of the "ecological restoration" session of the symposium. In: Proceedings of Ecology and Management of PinyonJuniper Communities Within the Interior West; 15-18 September 1997. RMRS-P-9. Ogden, UT: US Department of Agriculture, Forest Service, Rocky Mountain Research Station. p 271-277.

Clary, W. P., M. B. Baker, JR., P. F. O'Connell, T. N. Johnsen, Jr., and R. E. CAmpBell. 1974. Effects of pinyon-juniper removal on natural resource products and uses in Arizona. Research Paper RM-128. Washington, DC: US Department of Agriculture, Forest Service. 28 p.

Eddleman, L. E. and R. M. Miller. 1992. Potential impacts of western juniper on the hydrologic cycle. In: W. P. Clarey, E. D. McArthur, D. Bedunah, and C. L. Wambolt (comps.), Proceedings of the Symposium on Ecology and Management of Riparian Shrub Communities; 29-31 May 1991; Sun Valley, ID. General Technical Report INT-289. Ogden, UT: US Department of Agriculture, Forest Service. p 176-180.

Evans, S. G., AND J. P. Workman. 1994. Optimization of range improvements on sagebrush and pinyon-juniper sites. Journal of Range Management 47:159-164.

FRIED, B. M. 1993. Using valuation functions to estimate change in the quality of a recreational experience: elk hunting in Oregon [thesis]. Corvallis, OR: Oregon State University. $93 \mathrm{p}$.

HawkIns, R. H. 1987. Applied hydrology in the pinyon-juniper type. In: R. L. Everett (comp.), Proceedings of the Pinyon-Juniper Conference; 13-16 January 1986; Reno, NV. General Technical Report GTR-INT-215. Ogden, UT: US Department of Agriculture, Forest Service, Intermountain Research Station. p 493-504. 
IsLEY, A. 1984. Mechanical control of western juniper. In: Proceedings of the Western Juniper Management Short Course; 15-16 October 1984; Bend, OR. Corvallis, OR: Oregon State University Extension Service and Department of Rangeland Resources. p 61-68.

Johnson, P., A. Gerbolini, D. Ethridge, C. Britton, and D. Ueckert. 1999. Economics of redberry juniper control in the Texas Rolling Plains. Journal of Range Management 52:569-574.

Kerns, L., B. Turner, F. Obermiller, J. Tanaka, B. Eleveld, D. Chamberlain, G. Delaney, R. Hathaway, D. KNUtSON, AND W. Riggs. 1997. Enterprise budget: 350 cow/calf operation, High Desert Area. EM8470. Corvallis, OR: Oregon State University Extension Service. $4 \mathrm{p}$.

Martin, R. E. 1978. Fire manipulation and effects in western juniper (Juniperus occidentalis Hook.). In: Proceedings of the Western Juniper Ecology and Management Workshop; January 1997; Bend, OR. General Technical Report PNW-74. Portland, OR: US Department of Agriculture, Forest Service, Pacific Northwest Forest and Range Experiment Station. p 121-136.

OGDEN, P. R. 1987. Simulation model to test economic consequences of management decisions for a steer operation on pinyon-juniper woodlands. In: R. L. Everett (Comp.), Proceedings of the Pinyon-Juniper Conference; 13-16 January 1986; Reno, NV. General Technical Report GTR-INT-215. Ogden, UT: US Department of Agriculture, Forest Service, Intermountain Research Station. p 183-187.

SHORT, H. L., AND E. L. Boeker. 1977. The use of natural and modified pinyon pinejuniper woodlands by deer and elk. Journal of Wildlife Management 41: 543-559.

Sneva, F. A., and D. N. Hyder. 1962. Estimating herbage production on semiarid ranges in the intermountain region. Journal of Range Management 15:88-93.

Sorg, C. F., and L. J. Nelson. 1986. The net economic value of elk hunting in Idaho. Research Bulletin RM-12. Fort Collins, CO: US Department of Agriculture, Forest Service, Rocky Mountain Research Station. $21 \mathrm{p}$.

Suluivan, J. 1994. Callipepla squamata. Available at: http://www.fs.fed.us/ database/feis/animals/bird/casq/all.html. Accessed 1 April 2002.

[USDA] US Department of Agriculture. 1979. Wildlife habitats in managed forests: The Blue Mountains of Oregon and Washington. In: J. W. Thomas (TECH. ED.) Agriculture Handbook No. 553. Washington, DC: US Department of Agriculture, Forest Service. $512 \mathrm{p}$.

[USDA] US Department of Agriculture. 1990. Field Office Technical Guide: Range Interpretations: TCH—MLRA B10 Site Descriptions. Portland, OR. Soil Conservation Service SCS-OR MLRA B10.

VaitKus, M. R., and L. E. Eddleman. 1987. Composition and productivity of a western juniper understory and its response to canopy removal. In: R. L. Everett (CoMP.), Proceedings of the Pinyon-Juniper Conference; 13-16 January 1986; Reno, NV. General Technical Report GTR-INT-215. Ogden, UT: US Department of Agriculture, Forest Service, Intermountain Research Station. $p$ 456-460.

Williams, G., G. F. Gifford, and G. B. Coltharp. 1972. Factors influencing infiltration and erosion on chained pinyon-juniper sites in Utah. Journal of Range Management 25:201-205.

\section{APPENDIX}

The appendix contains descriptions of the variables (Table 7) and the equations used in the GAMS multiperiod linear programming model.

Table 7. Variables used in the model equations.

\begin{tabular}{ll}
\hline$z$ & Present value of net returns \\
$T_{\mathrm{t}}$ & Total revenue in year $t$ \\
$\mathrm{VC}_{\mathrm{t}}$ & Variable costs in year $t$ \\
$\mathrm{r}$ & Real discount rate \\
COW $_{\mathrm{T}}$ & Number of cows in the terminal year $T$ \\
\hline
\end{tabular}

Table 7. Continued

first $_{T}$

sellcow

netrev

sellcow

sellyear $_{t}$

sellcalff $t_{t}$

sellcalfm

coww $_{t}$

yearw

calff $w_{t}$

calfmw $w_{t}$

mktcow

mktyear

mktcalf

cowcst

cow $_{\mathrm{t}}$

first

feed $_{\mathrm{fs}, \mathrm{t}}$

feedcst $t_{\mathrm{fs}}$

plvalue $_{\mathrm{plpnt}, t}$

lambda ${ }_{\text {plpnt }}$

treatcst $_{\mathrm{mt}}$

trtcst $_{m t}$

IJA $A_{a, m i, g, p z}$

PUA $A_{a, m i, g, p z, m t, t}$

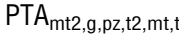

$\operatorname{cow}_{\mathrm{t}=0}$

first $_{\mathrm{t}=0}$

repl $\left.\right|_{t=0}$

clf

repl $_{t}$

rain

ppt

$h v_{t, g}$

AUDreq

utstndrd $_{\mathrm{g}}$ irrAUD

pubAUD

ptlyield $_{\mathrm{g}, \mathrm{pz}}$

$\mathrm{NJA}_{\mathrm{g}, \mathrm{pz}}$
Number of heifers calving for the first time in the terminal year $T$

Number of cows culled in the terminal year $T$

Ranch net revenues in the terminal year $T$

Number of cows culled in year $t$

Number of yearling heifers culled in year $t$

Number of heifer calves sold in year $t$

Number of steer calves sold in year $t$

Cow selling weight

Yearling heifer selling weight

Heifer calf selling weight

Steer calf selling weight

Cow selling price per cwt

Yearling selling price per cwt

Calf selling price per cwt

Variable monthly cow cost without forage costs

Number of cows in year $t$

Number of heifers calving for the first time in year $t$

Number of AUDs supplied from a forage supply in time $t$

Cost of forage supply ( $f s$ ) (\$ per AUD)

Values used to approximate exponential increase in cost of private lease

Step variables to approximate exponential increase in cost of private lease

Cost of juniper treatment method $(m t)$ incurred in time $t$ Treatment cost per hectare for method $(m t)$

Initial juniper-encroached hectares of cohort age $a$ and treatment method $m i$, in location $g$ (riparian or upland) and precipitation zone $p z$

Previously untreated juniper hectares of cohort age $a$ and treatment method $m i$, in location $g$ (riparian or upland) and precipitation zone $p z$, treated with method $m t$ in time $t$

Juniper hectares previously treated in time $t 2$ using method $m t 2$, in location $g$ (riparian or upland) and precipitation zone $p z$, retreated with method $m t$ in time $t$

Number of cows in year $t=0$

Number of first time heifers in year $t=0$

Number of calves held for replacement purposes in year $t=0$

Percent calving success

Number of calves held for replacement purposes in year $t$

Precipitation

Median crop year precipitation

Total herbaceous vegetation production in year $t$ in location $g$

AUD requirement (pounds of forage required per day) Utilization standard for forage location $g$

AUDs supplied by flood irrigated lands

AUDs supplied by public lease

Potential yield (Ibs of forage per hectare) in location $g$ and precipitation zone $p z$

Non-juniper-encroached hectares in location $g$ and precipitation zone $p z$ 
Table 7. Continued

\begin{tabular}{|c|c|}
\hline yieldcurve $_{\text {sage,mi,pz }}$ & $\begin{array}{l}\text { Actual yield as a percent of potential yield as a function of } \\
\text { stand age (sage), method of treatment }(m \imath) \text {, and } \\
\text { precipitation zone }(p z)\end{array}$ \\
\hline$A_{t}$ & Tons of soil loss in year $t$ \\
\hline $\mathrm{R}$ & Rainfall erosivity factor \\
\hline K & Soil erodibility factor \\
\hline LS & Slope gradient and length factor \\
\hline $\mathrm{C}_{\text {sage,mi,pz }}$ & $\begin{array}{l}\text { Cover factor as a function of stand age (sage), method of } \\
\text { treatment }(m i) \text {, and precipitation zone }(p z)\end{array}$ \\
\hline deer $_{t}$ & Deer population in year $t$ \\
\hline$d_{h}$ & Deer population as a function of habitat $h$ \\
\hline elk & Elk population in year $t$ \\
\hline$e_{h}$ & Elk population as a function of habitat $h$ \\
\hline$Q_{t}$ & Quail population in year $t$ \\
\hline quail $_{\text {sage }}$ & Number of quail per hectare given a particular stand age \\
\hline
\end{tabular}

$\sum_{m t 3} \sum_{t t 3=t+1}^{T T} \mathrm{PTA}_{m t, g, p z, t, m t 3, t t 3}$

$$
\begin{aligned}
& =\sum_{a} \sum_{m i} \mathrm{PUA}_{a, m i, g, p z, m t, t}+\sum_{m t 2} \sum_{t 2=1}^{t-1} \mathrm{PTA}_{m t 2, g, p z, t 2, m t, t}[13] \\
& \sum_{f_{s}} \text { feed }_{f s, t} \geq 365\left(\text { cow }_{t}+0.75 \text { first }_{t}+0.6 \text { repl }_{t}\right) \\
& \text { feed }_{f s=\text { unirr }, t} \leq \sum_{g}\left(\frac{111\left(\frac{\text { rain }}{\mathrm{ppt}}\right)-10.6}{100}\right)\left(\frac{b v_{t, g}}{\text { AUDreq }}\right) \text { utstndrd }{ }_{g}[15] \\
& \text { feed }_{f_{s}=\text { floodirr }, t} \leq \operatorname{irrAUD} \\
& 245\left(0.6 \text { repl }_{t}\right) \leq \text { feed }_{s=\text { floodirr }, t} \\
& \text { feed }_{f s=\text { public }, t} \leq 120\left(\text { cow }_{t}+0.75 \text { first }_{t}\right) \\
& \text { feed }_{f s=\text { public }, t} \leq \text { pubAUD } \\
& \text { feed }_{f s=\text { hay }, t} \geq 120\left(\text { cow }_{t}+0.75 \text { first }_{t}+0.6 \text { repl }_{t}\right) \\
& \sum_{g} \sum_{p z}\left(\sum_{a=64} \mathrm{PUA}_{a, m i=c u t, g, p z, m t=b u r n, t}+\sum_{a=74} \mathrm{PUA}_{a, m i=b u r n, g, p z, m t=b u r n, t}\right. \\
& +\sum_{t 2=0}^{t-63} \mathrm{PTA}_{m t 2=c u t, g, p z, t 2, m t=b u r n, t} \\
& \left.+\sum_{t 2=0}^{t-73} \mathrm{PTA}_{m t 2=b u r n, g, p z, m t=b u r n, t}\right)=0 \\
& \sum_{g} \sum_{p z}\left(\sum_{a=0}^{9} \mathrm{PUA}_{a, m i=c u t, g, p z, m t=b u r n, t}\right. \\
& \left.+\sum_{t 2=t-11}^{t-1} \mathrm{PTA}_{m t 2=c u t, g, p z, t 2, m t=b u r n, t}\right)=0
\end{aligned}
$$

$$
\mathrm{VC}_{t}=12 \cdot \operatorname{cowcst} \cdot\left(\operatorname{cow}_{t}+\text { first }_{t}\right)
$$$$
+\sum_{f s}\left(\text { feed }_{f s, t} \cdot \text { feedcst }_{f s}\right)
$$$$
+\sum_{p l p n t}\left(0.2583+0.00001 \cdot \text { plvalue }_{p l p n t, t}\right)
$$$$
\text { - } \text { plvalue }_{p l p n t, t} \cdot \operatorname{lambda}_{p l p n t, t}
$$$$
+\sum_{m t} \text { treatcst }_{m t, t}
$$

$$
\begin{aligned}
\text { treatcst }_{m t, t}=\sum_{g} \sum_{p z} & \left(\sum_{a} \sum_{m i} \operatorname{trtcst}_{m t} \cdot \mathrm{PUA}_{a, m i, g, p z, m t, t}\right. \\
& \left.+\sum_{m t 2} \sum_{\mathrm{tt} 2=0}^{t-1} \operatorname{trtcst}_{m t} \cdot \mathrm{PTA}_{m t 2, g, p z, t 2, m t, t}\right)
\end{aligned}
$$

$$
\operatorname{cow}_{t=0}=298
$$$$
\text { first }_{t=0}=52
$$$$
\text { repl }_{t=0}=111
$$

sellcalfm ${ }_{t}=\left(\operatorname{cow}_{t}+\right.$ first $\left._{t}\right) \cdot$ clf $\cdot 0.5$

sellcalff $_{t}+$ repl $_{t+1}$

$$
=\left(\operatorname{cow}_{t}+\text { first }_{t}\right) \cdot \mathrm{clf} \cdot 0.5
$$

repl $_{t}=$ first $_{t+1}+$ sellyear $_{t}$

sellyear $_{t} \geq 0.25 \mathrm{repl}_{t}$

sellcow $_{t} \geq\left(\right.$ cow $_{t}+$ first $\left._{t}\right) \cdot$ cull

$\begin{aligned} \sum_{m t} \sum_{t t} \text { first }_{t} & \leq 0.2 \mathrm{CUW}_{t}\end{aligned}$

$$
=\mathrm{IJA}_{a, m i, g, p z}
$$

Herbaceous vegetation for models that do not include juniper management options:

$$
\begin{aligned}
b v_{t, g}=\sum_{p z} \text { ptlyield }_{g, p z} & {\left[\operatorname{NJA}_{g, p z}\right.} \\
& \left.+\sum_{\text {sage }} \sum_{a} \sum_{m i}\left(\text { yieldcurve }_{\text {sage }, m i, p z} \cdot \mathrm{IJA}_{a, m i, g, p z}\right)\right][23]
\end{aligned}
$$

Herbaceous vegetation for models that $d o$ include juniper management options:

$$
\begin{aligned}
b v_{t, g}=\sum_{p z} \text { ptlyield }_{g, p z} & \cdot\left[\mathrm{NJA}_{g, p z}+\sum_{\text {sage }} \sum_{m t 3} \sum_{t t 3=t+1}^{T T}\right. \\
& \times\left(\sum_{a} \sum_{m i} \text { yieldcurve }_{\text {sage }, m i, p z} \cdot \mathrm{PUA}_{a, m i, g, p z, m t 3, t t 3}\right. \\
& \left.\left.+\sum_{m t 2} \sum_{t t 2=0}^{t} \text { yieldcurve }_{\text {sage }, m t 2, p z} \cdot \mathrm{PTA}_{m t 2, g, p z, t 2, m t 3, t t 3}\right)\right][24]
\end{aligned}
$$

Soil erosion and potential stream sedimentation for models that do not include juniper management options:

$$
A_{t}=\mathrm{RK}(\mathrm{LS}) \sum_{s a g e} \sum_{a} \sum_{m i} \sum_{g} \sum_{p z} C_{s a g e, m i, p z} \cdot \mathrm{IJA}_{a, m i, g, p z}
$$

Soil erosion and potential stream sedimentation for models that $d o$ include juniper management options: 
$A_{t}=\mathrm{RK}(\mathrm{LS}) \sum_{g} \sum_{p z} \sum_{\text {sage }} \sum_{m t 3} \sum_{t t 3}^{T T}\left(\sum_{a} \sum_{m i} C_{s a g e, m i, p z} \cdot \mathrm{PUA}_{a, m i, g, p z, m t 3, t t 3}\right.$ $\left.+\sum_{t 2=0}^{t} \sum_{m t 2} \mathrm{C}_{s a g e, m t 2, p z} \cdot \mathrm{PTA}_{m t 2, g, p z, t 2, m t 3, t t 3}\right)[26]$

deer $_{t, h}=d_{h}$

$\mathrm{elk}_{t, h}=e_{h}$

Quail populations for models that do not include juniper management options:

$$
\begin{aligned}
Q Q_{t}=0.5 \sum_{g} \sum_{p z} \mathrm{NJA}_{g, p z} & \\
& +\sum_{\text {sage }} \sum_{a} \sum_{m i} \text { quail }_{\text {sage }} \cdot \mathrm{IJA}_{a, m i, g, p z}
\end{aligned}
$$

Quail populations for models that do include juniper management options:

$Q Q_{t}=0.5 \sum_{g} \sum_{p z}\left[\mathrm{NJA}_{g, p z}+\sum_{\text {sage }} \sum_{m t 3} \sum_{t t 3=t+1}^{T T}\right.$

$$
\begin{aligned}
\times & \left(\sum_{a} \sum_{m i} \text { quail }_{\text {sage }} \cdot \mathrm{PUA}_{a, m i, g, p z, m t 3, t t 3}\right. \\
& \left.\left.\quad+\sum_{t 2=0}^{t} \sum_{m t 2} \text { quail }_{\text {sage }} \cdot \mathrm{PTA}_{m t 2, g, p z, t 2, m t 3, t t 3}\right)\right]
\end{aligned}
$$

